\title{
From Local to Global- Indian Organic Produce an Overview
}

\author{
Baisakhi Mukherjee \\ Research Scholar, Department of Management Banasthali University Rajasthan, India
}

\begin{abstract}
Organic products have a growing market both in India and globally. The study focuses to explore the strengths and weaknesses of this industry so as to tap the global demand and achieve the export target for organic products. The study will aim to perform SWOT analysis and develop TOWS matrix which will provide an insight to the players of Organic market at all levels. The strategies framed are completely based on the researcher's interpretation of the information collected from secondary sources and telephonic interviews of the agencies.
\end{abstract}

Keywords: Export, Market development, Organic products, Opportunities, Strengths, Threats, Weakness.

\section{Introduction}

Organic agriculture is an age old concept of more than $19^{\text {th }}$ century. The evidences of organic farming can be evidenced in the work report of Sir Albert Howard (Garibay and Katke, 2003).The farmers started adopting the practice more vigorously after the emergence of Green Revolution in 1960. Since last two decade, the consumers have become more aware and educated about the concept of organic practices. This rise in the awareness and concern for the environmental conservation is in turn increasing the demand for the organic products throughout the globe (Radman,2005).

The sprouting market sector of organic products is one of the fast blooming industries of the world and will provide trade opportunities for both developing and developed economies. The global market of organic food products will grow from $10-15 \%$ to $25-30 \%$ (Yussefi and Willer, 2002). To support this demand the farmers are now adopting organic farming actively to get the advantage of price premiums for the increase value of the products. This current wave of organic farming among the farmers worldwide has resulted in the coverage of approximately 3.5 million hectares land under the concept of organic farming.

In India, though organic farming practices are being followed, but the global market share is very less in comparison to other exporters such as US, Canada, Holland and others ( Sikka et al.,2006). This study aims to explore the organic product industry of India from the perspective of global market. This study will reveal the existing opportunities and threats in the global market of organic products and also highlights the strengths and weaknesses of Indian organic produce to develop a competitive edge and strategies to enhance the export share for India.

\section{Literature Review}

There has been a thrust in both the domestic and international market for green products since last two decades (Paul et al., 2016). With the rise of environmental concern, health issues, declining nutritional values of food products causing life threatening diseases and many factors, the demand for organic products are increasing at a galloping rate. This increase in demand of the organic products worldwide will lead to a growth of approximately $15 \%$ concentrated mostly in the developed countries (Willer, 2004). The developing countries are also expanding their market base in the global niche but at a much slower rate than expected. In order to boost the sales of their organic produce in the developed country the developing countries like India should explore more on standardization of the products according to the taste and preferences of the international customers, availability of the products in right quantity and time, upgrade in the production technologies, certification and many more(Sikka et al.2006). For this, the traders of developing countries should explore the existing market for organic products of developing country (Garibay and Khatke, 2003).

According to the report of National Program on Organic production 2012, the market size for organic products is increasing rapidly with $47 \%$ in EU, $28 \%$ in USA, $28 \%$ in Canada remarkably. The market is also growing at a healthy rate in Italy and Singapore. Though a large percentage of this demand is fulfilled by the domestic producers of these countries, but there is a huge demand of many other commodities and quantities of the existing commodities too for which they are looking for importing organic products. This gap in demand and supply will give rise to opportunities for developing countries like India to explore.

According to a report "Indian Organic food Market-Yes bank", there are approximately 37 million hectares of organic farmland concentrated over 160 countries and 1.8 million producers engaged in the organic farming. 
Figure1: Distribution of organic agricultural land by region

\section{Source: SOEL.IFOAM 2010}

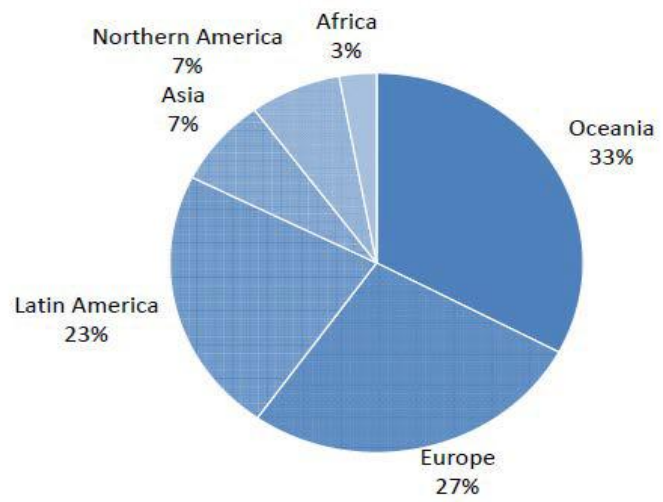

With the development of more regional markets and trading blocs the demand for organic products is spreading its roots to the developing countries like India too. The producers and marketers are getting attracted to the export benefits of the organic products and are looking forward to increase the production of the organic products. The Table 1 shows the major market for the organic products in Billion USD.

Table 1: major market for the organic products in Billion USD

\begin{tabular}{|l|l|}
\hline Major Markets & BN USD \\
\hline USA & $26 \mathrm{BN} \$$ \\
\hline Europe & $12 \mathrm{BN}$ \$ \\
\hline Japan & $3 \mathrm{BN}$ \$ \\
\hline Others & $10 \mathrm{BN}$ \$ \\
\hline
\end{tabular}

Source: Yes Bank Report 2010.

Japan is considered to be the largest market for organic products among the Asian countries with low domestic supply to combat the high demand for organic food and beverages (Yossefi et al.,2002 ; Hiraga 2002). It has to import a large share of organic products to meet the growing demand especially of organic food, but irrespective of this challenge, Japan strictly follows the certification and quality standard of the nation and only imports from the agencies that satisfy the criteria and the products are labeled by Japanese certifying agencies (Yossefi et al.,2002). This highlights an objective of this study to explore the current scenario of certification agencies of India and their strengths and weaknesses to capture the global opportunities.

According to a study, Japan has been highlighted as the largest market for food in Asia and it is likely to grow by approximately $40 \%$ in the near future (Hiraga, 2002) which can become an enormous opportunity for developing country like India to mark its presence in the global market for organic products. According to a market research report, it has been found that the US market for organic products is also blooming with a recorded sales of $26 \mathrm{BN} \$$ and has become the world's largest retail market for organic products (Kortbech, 2002; Garibay et al., 2003 ). This upsurge of demand is because of the rising awareness and concern to the depletion of environmental balance and health factors (Hult, 2011; Maignan and Ferrell , 2004 ; Banerjee et al., 2003 ; Karna et al., 2003). In US the organic products are made available through the use of different sources such as natural food stores, conventional grocery stores and direct to customers. This reveals that the availability of the product at maximum possible places plays a major role in the expansion of the industry throughout the world. The US consumers favor the fresh produces the most among the other organic products which is followed by non-dairy beverages, packaged, frozen and dried items of organic product line (Greene, 2002). The study highlights that sale opportunities exist in the product categories such as tropical products, off-seasonal and seasonal fruits and vegetables and processed foods (Kortbech, 2002). Regarding the pricing, the Table 2 shows the price premiums the international consumers likely to accept. This will also provide a fair overview about the realistic price base the exporter should consider.

Table 2: Price premium in Key Demand Centres

\begin{tabular}{|l|l|}
\hline Market & Price premium \% above conventional \\
\hline United States & $10-30$ \\
\hline United Kingdom & $30-50$ \\
\hline Japan & $10-20$ \\
\hline Germany & $35-100$ \\
\hline Austria & $25-30$ \\
\hline Denmark & $20-30$ \\
\hline
\end{tabular}

Source: Organic Monitor 
The European market has undergone a vigorous expansion (Hamm et al., 2002 ; NPOP Report 2012) in the organic industry. Though the countries within EU are expanding at a varied rate Germany and United Kingdom has the strongest market for organic products in comparison to Austria, Denmark, France, Holland, Italy(Hamm et al., 2002). Irrespective of the fact that $15 \%$ of the market is being captured by the domestic producers but still the market is confined to a narrow product range which reveals another opportunity to target for the Indian exporters ( Kilcher,2001)

The study emphasis on the fact that the main challenge to enhance the global competitiveness for organic products is to meet the quality standard and certification of the major market of the industry followed by the logistics to make the product available at the shortest possible time, maintain the quality and nutritional values of the products. This study mainly aims at the strategic analysis of the Indian export market for organic products with the help of SWOT analysis and TOWS matrix. This result of this study will pave the way for the future research in the field to review their strategies and identify the opportunities and threats.

\section{Indian Organic Market-Study And Analysis}

Organic products can be differentiated from the synthetic products on the basis of the production process being adopted and the use of ingredients for the production. As worldwide accepted the organic products can be defined as the products which are produced without the use of any chemicals substances. These are the products that are not harmful to the wellbeing of the human, animal as well as the environment (Sikka,B et al., 2006). Agriculture in India contributes approximately $24 \%$ in the GDP of Indian economy (Planning Commission, 2002), which accounts to $7.68 \%$ of the global agriculture(Statisticstimes.com).until 2005, 2.5 million hectare of farmland in India was concentrated in organic production which has increased to 21 lakh hectare by 2012 (NPOP, 2012). This shows a remarkable leap in the production of organic production but still a long way to achieve the target of global competitiveness and boost export of the Indian organic produce (Bhattacharya, P and Kumar, D. 2005).

Table. 3: The year wise growth of area under organic farming

\begin{tabular}{|l|l|}
\hline Year & Area in Hecatre \\
\hline $2003-04$ & 42,000 \\
\hline $2004-05$ & 76,000 \\
\hline $2005-06$ & $1,73,000$ \\
\hline $2006-07$ & $5,38,000$ \\
\hline $2007-08$ & $8,65,000$ \\
\hline $2008-09$ & $12,07,000$ \\
\hline $2009-10$ & $10,85,648$ \\
\hline
\end{tabular}

Source: National center of Organic Farming, Ghaziabad

According to National Project on Organic Farming, Indian farmers can be differentiated into three main sectors namely unorganized, semi organized and commercial. The unorganized segments of farmers are those who are following the organic agriculture methods as their forefather's tradition. This segment is well tagged as "organic by default"(Garibay et al., 2003). The second segment is comprised of the producers who have converted to organic farming after realizing the rising cases of health hazards and ecological imbalance due to agro-chemicals techniques of production. The declining of soil fertility, increasing issues of food toxicity and costs and less returns compelled them to convert to organic farming. The third category is the commercial producers who are mainly attracted to the price premium and market potential of the organic industry.

Ironically the first category which consists of a major percentage of agricultural produce is uncertified and the third category which is countable is the only certified player of the industry. The second category mostly consists of those producers or traders who are reluctant for certification due to lack of awareness or the high cost of certification. Presently the domestic market for organic products is estimated to be approx. 21 lakh hectares (NPOP). Noting the profitability and scope of expansion, corporate houses are also coming forward and started taking active participation in the promotion of organic industry. In this regard various agencies both in public and private sector are also cropping up.

\begin{tabular}{l} 
Exhibit 1: Case Study: Organic India \\
\hline Organic India is one of the major contributors in the Organic Industry. It has witnessed a big leap of growth \\
in the revenue from INR 25 crore in 2008 to INR 175 crore in 2013 . Organic India is very popular for its \\
green tea especially Tulsi (Holy Basil) tea. It has also introduced a wide range of organic products. \\
According to the CEO and Managing Director, the potential of organic market both domestic and \\
international is profuse and promising and as a result the company aims to introduce 20 standalone stores \\
across the country by the end of 2015 with some more addition in the product line.
\end{tabular}

Source: Secondary Data 


\section{Exhibit 2: Case study: Conscious Food}

Conscious food, a remarkable player of the organic industry has started a concept of farmer's market where the farmers can sell their organic produce direct to the customer without any middlemen intervention every

Sunday at Maharashtra Natural Park, Mumbai. India.

Source: Secondary Data.

In the present scenario, organic industry is considered as a blooming industry and only after realizing the benefits of organic products to the environment and health of the consumers, people have started actively participating and accepting the concept of organic products.

Indian government have designed several programs regarding educating the farmers about the new technologies of organic agricultural practices, certification, grading of the products. The government is also providing the market linkages for the producers to identify the buyers of their products easily (Exim Bank 2003).

To achieve the export target the Indian organic industry will need to adopt the following two approaches:

- Certifying the "organic by default" segment of the organic producers to balance the demand supply of the domestic market and enhance the surplus to export.

- India should focus in the export oriented production of the organic products mainly adding more varieties in the items i.e product depth. This will develop a competitive edge of organic produce at the global market.

Presently the major organic product items that are exported by India are mentioned in the Table 4.

Table 4: Majority of organic product items exported in tones.

\begin{tabular}{|l|l|}
\hline Tea & 3000 \\
\hline Coffee & 1000 \\
\hline Rice(Basmati) & 3500 \\
\hline Wheat & 1450 \\
\hline Pulses & 600 \\
\hline Spices & 1200 \\
\hline Fruits & 1800 \\
\hline Nuts & 375 \\
\hline Cotton & 2000 \\
\hline Herbal & 250 \\
\hline
\end{tabular}

\section{Source: $A P E D A$}

Before targeting the global market of organic products Indian organic industry have to address the issues concerning to develop an appropriate marketing mix. The targeting marketing mix should answer

- how to maintain quality consistency irrespective of the quantity

- what should be the positioning strategy of organic products at the global platform in the terms of standard or polycentric.

- On what basis market segmentation will be done?

\section{Analysis}

SWOT analysis has been conducted on the basis of the information obtained from secondary sources and literature review on the basis of which TOWS matrix has been developed which will provide an insight to the exporters and other players to review their strategies and identify the research gaps for the future research.

Table 5: SWOT

\begin{tabular}{|c|c|c|c|}
\hline Strengths & Weakness & Opportunity & Threats \\
\hline 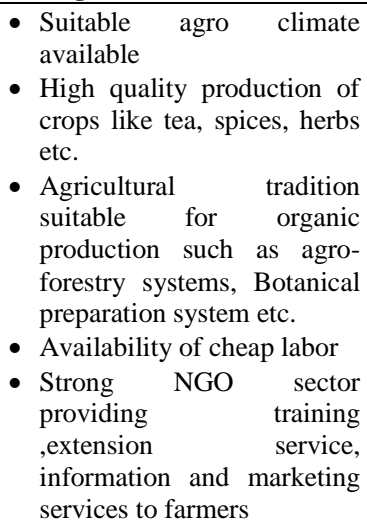 & $\begin{array}{l}\text { - } \begin{array}{l}\text { Lack of } \\
\text { infrastructure }\end{array} \\
\text { - } \text { Lack of quality control } \\
\text { mechanism } \\
\text { - Limited shelf life of the } \\
\text { products } \\
\text { - Lack of farmer's } \\
\text { awareness and training } \\
\text { about agriculture practices } \\
\text { - Lack of market } \\
\text { intelligence } \\
\text { - Lack of market research } \\
\text { and study. } \\
\text { Inadequate post harvest } \\
\text { management } \\
\text { - Lack of R\&D base in }\end{array}$ & 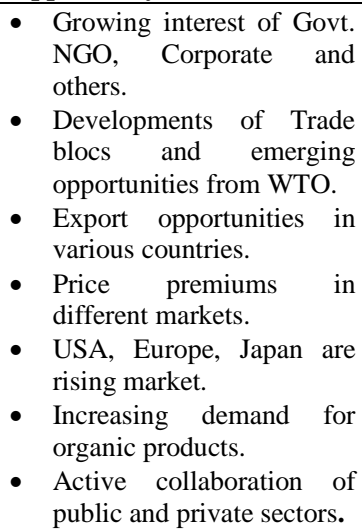 & $\begin{array}{l}\text { - Tariff and non tariff } \\
\text { barriers } \\
\text { - Quality tests and } \\
\text { certification is one of the } \\
\text { biggest hinder. } \\
\text { - Winning trust of both the } \\
\text { domestic and } \\
\text { international consumers. }\end{array}$ \\
\hline
\end{tabular}


- Indian corporate are also willing to invest.

- Active participation of Government. organic production

- $\quad$ Certification, grading and low consistency of quality and problem of contamination.

- Minimal access international market

\begin{tabular}{|l|l|l|}
\hline of & & \\
of & & \\
to & & \\
\hline
\end{tabular}

Table 6: TOWS matrix

\begin{tabular}{|c|}
\hline SO: Strengths-Opportunity Strategy \\
\hline $\begin{array}{l}\text { - } \quad \text { Appropriate marketing mix should be designed focusing the target market. } \\
\text { - } \quad \text { Vigorous research in this field should be encouraged at all levels to identify the gaps. } \\
\text { - } \quad \text { More export zones for organic products should be developed. } \\
\text { - } \quad \text { Conversion of farmlands using chemicals for production to organic farming should be encouraged at a large scale. } \\
\text { - } \quad \text { Public - Private partnership should be developed to carry out marketing and research of the organic products. } \\
\text { - } \quad \text { New market and new product development should be established to achieve competitive advantage. }\end{array}$ \\
\hline WO: Weakness-Opportunity Strategy \\
\hline 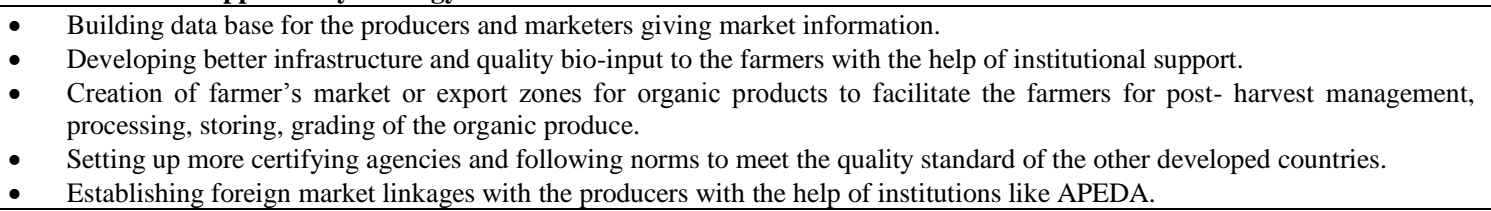 \\
\hline ST: Strengths-Threats Strategy \\
\hline $\begin{array}{ll}\text { - } & \text { Quality and consumer oriented products } \\
\text { - } & \text { Well designed positioning and branding strategies. } \\
\text { - } & \text { New product and market development strategies. }\end{array}$ \\
\hline WT: Weakness-Threats Strategy \\
\hline
\end{tabular}

\section{Conclusion}

Organic agriculture and organic consumerism is still at its nascent stage and the potential is yet to be explored. The organic culture has the capability to combat the environmental problems which are on the rise at every sphere of the globe. Organic culture is being recognized by the government and international institutes and gradually consumers all over the world are also accepting the benefits of the organic products in their lifestyle. Global organizations like FAO, UNCTAD, UNESCO, are actively promoting the benefits and value of the organic culture and the extent it will contribute in the conservation of the ecology and human welfare.

India has the potential to exploit the galloping demand for organic products at international level and can achieve its export target if the large part of unorganized domestic market is organized and follow a definite production and marketing strategy (Donith, N.R.2001). India should focus in new product and market development to meet the demand of quantity as well as in terms of product variety. This in turn will develop competitive advantage for the Indian organic produce in the global market to explore the blasting opportunity as shown in Table7.

Table 7: Projected Growth of various organic items.

\begin{tabular}{|l|c|}
\hline Product & \% Projected Growth in the 5 next Years \\
\hline Spices (all) & 14 \\
\hline Pepper & 5 \\
\hline Turmeric & 4.5 \\
\hline Tea & 13 \\
\hline Rice & 10 \\
\hline Fruits (all) & 8 \\
\hline Banana & 15 \\
\hline Mango & 5 \\
\hline Orange & 5 \\
\hline Pineapple & 5 \\
\hline Herbal extracts & 7 \\
\hline Cotton & 7 \\
\hline Coffee & 5 \\
\hline Oil seeds & 5 \\
\hline Honey & 5 \\
\hline Groundnut & 5 \\
\hline Baby food & 5 \\
\hline Coconut & 5 \\
\hline
\end{tabular}

Source: Secondary Data 


\section{Limitations}

Due to the competitive factor many of the government institutions and agencies were not willing to share their data and those who have provided their opinions their identity were not disclosed on their request. Therefore, the study has to depend a lot on the data obtained through literature review and reliable secondary sources as archives of APEDA, National organic centers of agriculture, Exim bank, export agencies . the conclusions and the recommendation are completely on the basis of the researchers interpretations of the data available.

\section{References}

[1]. Bhattacharya, P. and Kumar, D. 2005. National Policy on Promoting Organic farming, Proceedings of National Seminar, March 1011,2005. National Centre of Organic Farming, Ghaziabad, India.

[2]. Centre for Science \& Environment (CSE), Homicide by Pesticides, Centre for Science \& Environment, New Delhi, 2000

[3]. Department of Agriculture, Govt. of U.P., Data collected by Centre for Energy Environment \& Technology, Administrative Staff College of India, Bella Vista, Hyderabad, 2002.

[4]. Department of Chemicals \& Petro-Chemicals, Indian Chemical Statistics 2000-01, Ministry of Chemicals \& Fertilisers, Govt. of India, New Delhi, 2001

[5]. Donthi N. R.,2001 “ Organic Farming in India: Poised for Growth in the New Millennium," Proceedings of the Fifth IFOAM Asia Scientific Conference, Hangzhou, China,

[6]. Economic Survey of India 2003, Ministry of Finance, Government of India, New Delhi, 2003.

[7]. Exim Bank, 2003. "Export of Organic Products from India. Prospects and challenges" Occasional Paper No.97. Export-Import Bank of India.

[8]. Garibay S V and Jyoti K, 2003. "Market Opportunities and Challenges for Indian Organic Products”, Study funded by Swiss State Secretariat of Economic Affairs.

[9]. Hamm, Gronefeld and Halpin, Analysis of the European Market for Organic Food, School of Management and Business, University of Wales Aberystwyth, UK, 2002

[10]. Kortbech-Olesen Rudy, Export Opportunities of Organic Food from Developing Countries, WorldOrganics 2000 London, United Kingdom, 9-10 May, 2000.

[11]. Kortbech-Olesen Rudy, 2003. "Overview on World Trade in Organic Food Products: the US market and recent trends", BioFach Congress, Nuremberg, Germany

[12]. National Program for Organic production Report 2012.

[13]. Planning Commission, Tenth Five Year Plan, Planning Commission, Government of India, New Delhi, 2002

[14]. Planning Commission, Organic and Biodynamic Farming, Report of the Working Group, Government of India, New Delhi, 2001.

[15]. Radman,M. ,2005 “Consumer consumption and perception of organic products in Crotia” British Food Journal, Vol.107, Issue-4,pp 263-273.

[16]. Sikka, B.K ,Narula, S.A, Jairath, M.S., 2006. “ Enhancing Global Competitiveness of Indian Organic Produce: Opportunities, Challenges and Strategies."

[17]. Sikka,B.K., C.S. Vaidya and M.L. Sharma, 2005 "Problems and Potentials of Organic Farming in Western Himalayan Region of India, International Conference on Plasticulture and Precision Farming (Book of Abstracts), New Delhi, India.Pp 359-360.

[18]. SoEL Survey, 2003 downloaded in April 2003 from www.soel.de/oekolandbau/welweit_reports.html

[19]. The Fertilizer Association of India, Bio-fertilizer Statistics 1999-2000, The Fertilizer Association of India, New Delhi, 2001.

[20]. THIRTY-SEVENTH REPORT STANDING COMMITTEE ON PETROLEUM \& CHEMICALS, Production and Availability of Pesticides Ministry of Chemicals and Fertilisers (Department of Chemicals \& Petrochemicals), New Delhi, 2002.

[21]. Wadhwa Pawan, September 18-20, 2001 “An Overview Of The IPSN Program in India”Paper presented at Regional Workshop on Integrated Plant Nutrition System (IPNS) Development \& Rural Poverty Alleviation, Bangkok,.

[22]. Yes Bank Report, 2010," Organic Market in India"

[23]. Willer.H and Yussefi, M 2004. “ The world of Organic Agriculture. The statistics and emerging Trends.”International Federation of Organic Agriculture Movements (IFOAM).

[24]. Yussefi ,M and Willer H. 2002. "Organic Agriculture Worldwide, Statistics and Future Prospects.” Stiftung Okologic and Landbau. Bad Durkheim, Germany.

[25]. Yussefi , M and Willer H. 2003, "The World of Organic Agriculture Statistics and Future Prospects", International Federation of Organic Agriculture Movements, 2003. 